\section{MEDICAL RADIOGRAPHIC TECHNIC}

By GlenN W. Files. (Chas. Thomas, Springfield, U.S.A.; Bailliere, Tindall \& Cox, Lonodn. 1944. 'Price 33s.

This book has been prepared by Members of the Technical Service Department of an American firm of manufacturers of X-ray equipment. The blurb on the titlepage of the wrapper claims that it has been written by technicians for technicians, and that for producing consistently better end results. Experts, who know how, show how with time-tested technical procedures. Further, this all-round, plainly written Source Book on X-ray technique copiously and ingeniously illustrated by $38 \mathrm{r}$ original, practical figures is the carefuHy prepared masterwork of widely experienced experts. The 364 pages, therefore, are almost more illustration than script.

The first 75 pages deal with fundamental electrical concepts, electron theory and the X-ray tube, basic X-ray generating circuits, $\mathrm{X}$-ray apparatus and radiographic calibration. The advanced mathematical formulae, the complicated circuits are mixed with such elementary facts that the instruction is too much for the beginner, and not enough for the expert electrical engineer.

In the next 90 pages there is a rapid review of the factors affecting the quality of the Radiograph, the Processing Room, Stereoscopy, Planigraphy, Fluoroscopy, and Soft Tissue Radiography.

Anatomy is dealt with in 35 pages, six of which are script, and the rest pictures. The latter are elementary but instructive.

Positioning and Technic. - 25 pages are allotted. The usual positions are well photographed, and there are corresponding radiographs: No advice is given as to why and which and when alternative positions should be used. Dental radiography is described in 14 pages, and in another 3 a description of what is now being called "Mass Radiography.",

As would be expected, the oritlook is definitely American; 60 cycles per second is usual in the electric supply systems of the Western Continent, but English readers should have been warned that the custom here is 50 cycles per second. A Kenotron would probably not be recognised by many radiographers here as being the same thing as a Valve.

The book is not sufficiently detailed to be sufficient for candidates for the M.S.R. examination, but it may be of help to them as a quick revision course, and perhaps to such as have to use the products of the firm responsible for the production of the book.

It is well printed, the illustrations are excellent, though the reproduction of the radiographs is scarcely in the same standard.

\section{HUTCHISONS LECTURES ON DISEASES OF CHILDREN}

\section{9th edition}

Revised by Alan Moncrieff. Edward Arnold \& Co., London. I944. Price 2 Is.

This popular book has been thoroughly revised by Dr. Moncrieff, and several valuable additions made. There is a new section on congenital heart disease, and on infant feeding, and an account of the Rhesus factor is included, also a note on encephalitis. There are other minor alterations, and some omissions from the previous edition.

In one or two respects the book nevertheless appears to devote over-much attention to some of the less important diseases of present-day practice at the expense of some of the commoner ones. For instance, there is still a long section on congenital syphilis, whereas bronchiectasis apparently merits merely a passing mention in a short article entitled "pulmonary fibrosis." There is no reference to glandular fever, although such conditions as primary amaurotic mental deficiency are described.

The conversational style of the original author has been everywhere retained, and most readers will agree that this is one of the very few text-books which it is a real pleasure to read. It contains much sound and practical information, and is of course especially strong on the therapeutic aspects. This is a book which all students should read, and doubtless most of them will.

\section{REHABILITATION, RE-EDUCATION AND REMEDIAL EXERCISES}

By Olive F. Guthrie Smith. Baillière, Tindall \& Cox, London. 1943. Price 25s.

I have read this book with great interest, yet with some disappointment, for though the magic word-Rehabilitation-appears on the cover and on alternate page headings throughout the volume, yet only a very small part of the text is devoted to modern rehabilitation clinic technique. - Rather is nearly two-thirds of the book and diagrams devoted to the treatment of injury or disease by resistance therapy aided by springs and pulleys. A procedure of which Mrs. Guthrie Smith is a well known advocate and has been for years. The present book deals at great length with the methods devised by her and is profusely illustrated with many excellent diagrams and photographs. Only in the last chapter written by Dr. Lanckenau is any help given to the seeker of knowledge who is looking for assistance in the planning and running of a modern Rehabilitation Clinic. Even here the subject is very sketchily dealt with, and little guidance is given as to the merits of individual or class treatment, specific or general exercises in the treatment of injuries. Whilst again no mention is made of the inhibitory factors of pain and higher centre reflexes as stressed in Griffiths' views on Rehabilitation, and the importance he lays in organised games in the Rehabilitation Clinic. The photographs of skin grafting technique would be excellent in a book of surgery but appear rather out of place in this book. In spite of these criticisms this book should have a place in the library of every physio-therapeutist.

\section{AIDS TO THEATRE TECHNIQUE (Nurse's Aids Series)}

By Marjorie Houghton, S.R.N., S.C.M., and Margaret Harding, S.R.C.N., S.R.N. Pp. 262, over Ioo illus. Glossary of Instruments. Messrs. Baillière, Tindall \& Cox. 1944. Price 4 s.

This little book dealing with theatre work, so ably 